\title{
Literatura
}





\section{Um país dentro da casa: \\ o caráter político \\ do espaço doméstico \\ em três romances brasileiros}

SIMONE ROSSINETTI RUFINONI I

Uma casa é as ruínas de uma casa, uma coisa ameaçadora à espera de uma palavra; desenha-a como quem embala um remorso [...]

(Manuel António Pina)

E pensei que, afinal, todas as casas, na sua fixidez, são estacas do mal [...]

(Lúcio Cardoso)

\section{Espaço e sociedade}

1

FEIÇÃO DE RETRATO do Brasil que subjaz à experiência do romance de 1930 - estampada seja pelo imperativo de verossimilhança, seja pelo decíclicas ou pela insurgência contra o modelo da vanguarda modernista - advém do caráter representativo mobilizado na intenção de captar o todo da nação. O desenho de país condicionado pela opção documental, em detrimento da literatura e da visada mítica ou experimental, ${ }^{1}$ faz pensar no predomínio dos espaços abertos e comuns, talvez cenário mais característico para a figuração dos conflitos sociais.

Contudo, na contramão dessa inferência, chama atenção que grande parte dos enredos do romance a partir dos anos 1930 se desenvolva rente à esfera do mundo privado por oposição ao público. Se a tendência à apreensão do real parece mais afeita tanto à escolha dos espaços compartilhados quanto à representação neorrealista - como ocorre, em graus diversos, com Parque industrial (1933), Os corumbas (1933), Cacau (1933) e Suor (1934) -, cabe ponderar a respeito da grande quantidade de obras que privilegiam os espaços menores, da vida doméstica, bem como da relação entre esses espaços, a sociedade e certa compleição formal.

Pode-se refletir sobre o assunto a partir da amplitude - assim como da incompreensão - que a prosa de tendência introspectiva adquire no período, para 
além da ultrapassada dicotomia entre regionalistas e intimistas. A observação tem relevância ao observar como a crítica do período privilegiou a experiência romanesca do que se convencionou chamar de "romance do Nordeste", considerado o caminho mais adequado para a elaboração eficaz da vida social.

Para além das classificações restritivas, em romances emblemáticos da década a presença do espaço da intimidade e das técnicas de introversão comparecem entrelaçados; sirvam-se os exemplos de dois romances diversos e seminais do período: São Bernardo, de Graciliano Ramos (1934), e Fronteira, de Cornélio Penna (1935). Com alterações de rumo e projeto, a potencialidade semântica e sociológica do espaço doméstico continua nas décadas seguintes como ocorre com Fogo morto, de José Lins do Rego (1943), A menina morta, de Cornélio Penna (1954), e Crônica da casa assassinada, de Lúcio Cardoso (1959). Trata-se de enredos que transcorrem no interior ou em torno das habitações, mais especificamente aquelas que foram ou são casas-grandes, impondo a presença de certa estrutura de poder como aspecto que se entronca, de modo vário, ao espaço romanesco. A recorrência ao espaço da casa, a análise e interpretação de suas consequências permitem entrever o complexo quadro de relações entre espaço, forma romanesca e sociedade brasileira na experiência posterior aos anos 1930 mais especificamente entre as décadas de 1940 até meados dos anos 1960 - com ênfase nos três romances acima elencados.

Em termos teóricos, o espaço acomoda-se mais imediatamente à tradição realista, em decorrência da primazia do caráter representativo, muita vez embebido em tonalidades científicas. Nesse sentido, a categoria pode ter sido relegada pela modernidade cujo princípio antimimético privilegiava a discussão acerca da autonomia dos procedimentos de linguagem, de certo modo negligenciando a sugestão ao extratextual que a espacialidade encerra (Brandão, 2013, p.22-4). ${ }^{2}$ Tal panorama permite pensar o sentido do espaço ficcional na cena literária brasileira posterior aos anos 1930, com foco nos três romances. Nesses, a utilização privilegiada do espaço é muito peculiar e se afasta de qualquer preocupação meramente empirista; as casas não são palco meramente mimético, com função cenográfica, pitoresca ou de representação direta do real. A presença determinante comparece diluída, uma vez que existe por meio e em função dos sujeitos. Trata-se de pensar uma categoria afeita à imitação, contudo submetida à elaboração antimimética do prisma introspectivo.

A casa é lócus muito peculiar: por um lado, é espaço do dentro por oposição ao espaço do fora ${ }^{3}$ mas o recesso da intimidade é um outro dentro para o qual a casa é também um fora, embora menos exteriorizada e mais restrita que o mundo comum. Configura um lugar que se entronca à intimidade e, ao mesmo tempo, acena com a virtualidade da dinâmica do mundo. Como uma série de encaixes, as espacialidades e seus sentidos se interpenetram.

Sabe-se que a casa é imagem que, quase um arquétipo, acolhe sentidos que se referem ao retorno à mãe, ao aconchego, à plenitude. A idealidade da 
morada pode estar contida nas imagens do casulo, do ninho ou da gruta, alusões a um estado de bem-estar primeiro e totalizante ao qual, contudo, a experiência do homem no mundo não parece acatar. ${ }^{4}$ Os romances desvelam a casa como lugar socialmente configurado, em nuances variegadas do exercício do poder. Não há como se furtar ao fato de que o predomínio da história como arbítrio e opressão infiltra-se e amalgama-se à constituição ficcional do espaço físico, evidenciando a condição incontornável de como esse se faz extensão do social. A casa não é um vazio, mas espaço do mundo. ${ }^{5}$

Afastada a pretensão da autonomia dos fenômenos, avulta o caráter político das casas: não mais redoma apaziguadora, mas receptáculo privilegiado da História - "As casas não são refúgios contra a história. É nelas que os fatos históricos vão desembocar". ${ }^{6}$ De modo que a suposta natureza primeira do lar inviolável não pode se eximir da totalidade das relações sociais; assim, a casa, literariamente delineada, configura-se "estrutura social em estado objetivado".

Acrescente-se a isso a condição local: para além do espaço objetivado da abstração espaço-social, a circunscrição literária da casa se comunica, sem ser mero reflexo, com o funcionamento e a estrutura de um determinado modo de produção. Para falar com Henri Lefebvre (2013, p.124), o espaço social está longe da acepção de natureza; não só reproduz, como intervém e sofre as transformações do modo de produção. Apesar de produto do momento histórico, ultrapassa a mera noção estática que atua sobre uma mercadoria ao abarcar uma rede dinâmica de relações sociais - daí ser "à sua maneira produtivo e produtor", ${ }^{8}$ ultrapassando o limite da superestrutura.

A esse quadro soma-se a especificidade da empresa rural brasileira, o âmbito da casa-grande como célula do poder, base do latifúndio escravocrata, cuja onipresença corta a experiência nacional. Sob esse aspecto, o espaço físico e literário da casa por vezes emula o próprio espaço social, espécie de construção em microcosmo, a um só tempo produto e produtor, cuja rede de relações que a sustém perfaz a base da economia monocultora. Mais do que um espaço social vago e amplo, a casa-grande literária vislumbra a base, a estrutura, em cujo bojo se desenvolve toda a complexa rede que, ancorada na família patriarcal, a ampara e propaga. Assim, apesar de alocada na categoria "espaço", cujas limitações referem-se à exterioridade e à localização geográfica, em detrimento da categoria "tempo", mais comumente associada à historicidade e à abordagem diacrônica, a casa faz parte de um conjunto estético-social que a desvenda como construção complexa, postulando a leitura da morada como categoria espaçotemporal.

Desse modo, a ressonância entre os romances Fogo morto (1943), de José Lins do Rego (1971), A menina morta (1954), de Cornélio Penna (2001), e Crônica da casa assassinada (1959), de Lúcio Cardoso (1997), permite interpretar a complexidade da dinâmica social brasileira captada pelos significados que o palco ficcional da vida privada pode compreender.

A aproximação entre as obras referendada pelo espaço físico acolhe uma 
série de características, desvendando-se recurso privilegiado da memória do Brasil arcaico. Os enredos transcorrem no interior ou à sombra das casas ruinosas que, guardiãs da memória e testemunhas da decadência, impõem-se como lugares de interdição à liberdade e ao processo de emancipação. Nessas residências, encenam-se, pelo viés intimista, os modos da sociabilidade brasileira ancorada na vivência doméstica, dada a quase inexistência do espaço externo. Os sentidos que o espaço incorpora expressam sua potencialidade como lócus capaz de conjugar tempo, história e formação do sujeito.

Importa acompanhar quais os matizes que o conjunto da casa assume ao incidir sobre as personagens; de que modo a dominação infiltra-se nas relações interpessoais moldando a voz e o lugar, o discurso e o corpo - a emancipação ou a sujeição do homem livre. Como a elaboração estética capta a dinâmica da grande propriedade, mundo e moldura da subjetividade.

Pode-se pensar que o olhar para o país como uma casa traduz um caminho crítico: um país cerceado quadra bem com a modernidade tardia e falhada, murada pelo atraso. Tais romances, ao apostar na parte que remete ao todo, elegem sujeito e vida miúda como condutores da vida social. Essa vida à roda da casa conduz necessariamente a escolhas narrativas e formais: o reduto do sujeito afina-se com procedimentos estéticos que logram desentranhar da densidade psicológica, da memória, dos acontecimentos fortuitos ou do dado comezinho, a complexidade da história. ${ }^{9}$

Romances como casas interiorizadas, que se dão a ver por meio de imagens ${ }^{10}$ cuja construção desenha uma casa-país. O pressuposto exige cuidado para com a complexidade que a categoria espaçotemporal sob a égide da casa configura. Não só cenário ou categoria teórica, nem tampouco mero reflexo do patriarcado ou lugar da introspecção, mas imagem e ambiência literária que açambarca diversos aspectos. ${ }^{11}$ Desse ponto de vista, a casa aqui observada compreende várias nuances articuladas em torno da estrutura de poder herdada da colônia e entroncada à formação da subjetividade burguesa

A materialidade literária da casa a concebe como categoria complexa em cujo amálgama se inscreve o país; assim, é enquanto imagem que a casa sugere outras roupagens - quais sejam: as de prisão, hospicio e, finalmente, espaço tumular. A par das diferenças, as reverberações de sentidos entre as obras referendam a objetividade da matéria social apreendida.

\section{Do refúgio ao cárcere: a casa como prisão}

É sob a égide dos casarões, índice da casa-grande enquanto estrutura de poder, que os três romances se desenrolam. O Santa Fé em Fogo morto, o Grotão, em A menina morta, e a chácara dos Meneses, em Crônica da casa assassinada. Nesses romances, a morada assume proporções surpreendentes, ultrapassando a mera dimensão do ingênuo recesso do lar e fortalecendo-se como imagem das estruturas de poder.

Peculiaridades da vida privada imprimem-se nas figurações da casa. Apesar 
de apenas uma das três partes do romance Fogo morto se deter no engenho Santa Fé, do coronel Lula, os outros espaços - a morada de Zé Amaro e a Vila do Pilar - estão condicionados temática e socialmente à casa-grande.

A segunda parte de Fogo morto - significativamente intitulada "O engenho de Seu Lula" - desenvolve-se sob a grande propriedade. A família empobrecida vive encarcerada. Tal acepção emerge no episódio em que Seu Lula se torna obcecado como uma suposta relação entre a filha Neném e um promotor, genro desqualificado aos olhos da fidalguia.

Começara a chover forte. As portas da casa-grande estavam fechadas. Saiu para examinar os ferrolhos, as trancas. Tudo estava muito bem fechado, Neném não viera para a mesa do chá. Quis que ela viesse. Mandou que a mulher fosse chamá-la. E quando a viu de olhos vermelhos de chorar, com a cabeça baixa, imaginou o ódio que não lhe teria. Era pai, e pai era somente para aguentar as fraquezas dos filhos. Estava sereno. Deus lhe dera calma, força para vencer os tumultos de sua alma. Não falou. Amélia parecia com medo de qualquer coisa. $\mathrm{O}$ vento batia nas portas, bulindo com os ferrolhos. Tudo estava muito bem trancado. Então, Seu Lula pôde olhar para a sua filha como uma propriedade sua, que ninguém tocaria. (Rego, 1971, p.188)

A narrativa continua acompanhando os eventos por intermédio da consciência de Lula de Holanda: encaminha-se ao quarto dos santos, vê D. Amélia a rezar e se pergunta o que ela pediria a Deus, rememora os anos de recém-casado e a ternura da filha pequena. Em seguida a casa se apaga, todos se recolhem. Olívia, a cunhada louca, segue gritando frases desconexas e a chuva continua a cair, pontuando a cena agônica, quando o coronel ouve os cascos de um cavalo. Logo fantasia o rapto de sua filha, supõe ser vítima de um complô e a ameaça da desonra aflora violentamente. De clavinote em punho sai para o terreiro e mata um cavalo que havia escapado do curral. Quando, na ordem do narrado, a sucessão dos eventos desvenda o erro, escancara-se a paranoia e o distúrbio. A imaginação da grandiosa ofensa - inimigos confabulam contra a nobreza do senhor que, heroicamente, faz justiça com as próprias mãos - seguida do choque diante da realidade mesquinha culmina em um ataque e o senhor cai, fulminado. Em tudo, a cena é a caricatura do mundo do poder senhorial, apequenado e doente, mas sem abrir mão da superioridade de classe que abre caminho para a insanidade.

O episódio desvenda a casa-grande como símile de uma prisão. A sinhazinha guardada a ferrolhos, o senhor de engenho de armas engatilhadas, a proteção que se confunde com a pena, o pai que se faz algoz. Do todo, desponta a face da casa como espaço de confinamento, algo bem diverso do acolhimento de um lar.

Cárcere também se faz a fazenda do comendador, o Grotão, palco de $A$ menina morta. O nome já contém algo de contraditório e sombrio: a grota, ou gruta que, segundo certa tradição, pode remeter ao espaço como refúgio aca- 
lentador passa, pelo aumentativo, acrescido dos sentidos contextuais, a conter o oposto: torna-se cenário lutuoso, mais afeito ao imaginário infernal. ${ }^{12}$

Poucos são os eventos do romance que ocorrem fora da casa. Cenas que são exceções, momentos que rompem com a normalidade, para que em seguida os moradores retornem à casa-claustro, onde se vive uma atmosfera de tempo em suspenso, carregada de energias individuais e coletivas represadas. Uma das recorrências importantes do espaço externo é a clareira. É dúplice a significação do local, divisor de águas da vida da matriarca Mariana: foi lá que conheceu o comendador, e consequentemente onde seu destino foi decidido, e é para lá que retorna a fim de fugir a casa. Também é digno de nota que, após o casamento de Celestina (a prima pobre e doente), Carlota observe que o casal, em vez de dirigir-se à vila, como seria o esperado, tome o caminho da clareira. $\mathrm{O}$ espaço natural funciona como antítese à ordem da casa, índice de fuga, transgressão ou liberdade. Outro episódio dos espaços abertos: ao final, após a traumática manumissão e a debandada geral, há uma cena externa digna da desordem em que o sujeito fora lançado. Carlota, a sinhá que aboliu a escravidão, a escrava Libânia e Manuel Procópio, o agregado - a herdeira, a escrava e o idoso de um país devassado aliam-se ante a tarefa funesta: sepultar Dadade, a negra meio feiticeira, cujas palavras cifram o destino da fazenda.

Assim, a casa se faz refúgio hostil. Para Libânia, a ama de leite da sinhazinha, o Grotão "lhe parecera sempre um palácio encantado e proibido" (Penna, 2001, p.37); Justino, o administrador, espanta-se ao "ver que lhe mandavam entrar no recesso da casa", pois "parecia-lhe uma audácia só o pensar que poderia ir lá e decerto não saberia orientar-se naquela grande casa" (ibidem, p.35); para D. Virgínia "cada dia que se passava a grande casa se lhe tornava mais hostil e perdia pouco a pouco a sua vitalidade e o seu palpitar largo e fecundo" (ibidem, p.101); Dona Violante diz estar diante de "grave sessão do parlamento do reino do Grotão" (ibidem, p.403); Para Sinhá Rola parecia "tudo ter se tornado hostil e estranho, e aquele quarto tão amado, seu refúgio de tantos anos, era agora o pouso banal de hotel de passagem, das estações de baldeação de suas raras viagens" (ibidem, p.469). O conflito entre sujeito e mundo - centro do romance como queria Lukács - molda-se à circunstância local: como não há espaço fora da esfera doméstica, o mundo reduz-se à morada que, fiel à historicidade, torna-se palco que absorve e desdobra o embate.

A prisão privada assenta sobre uma ambiguidade de fundo. Por um lado, trata-se da preservação do grupo contra a ameaça de dissolução, expressa pela emergência do mundo do trabalho livre. Daí que a preservação se articula à proteção; à ameaça sucede a defesa, legitimada em termos que radicam na ideologia da família, num caminho de legitimação de modos de violência. Sob esse prisma, note-se a presença maciça de mulheres na fazenda, em um romance voltado para personagens femininas. Tanto as sinhás, quanto as agregadas não devem ser vistas, ter voz ou presença: das primeiras espera-se o luxo da reclusão; das 
segundas, à condição feminina se acresce a necessidade de viver sorrateiramente, na condição de coadjuvantes.

Por outro lado, a suposta proteção é grave violação à individualidade e aos incipientes direitos do cidadão sob o mundo livre. A retórica em torno da preservação e da proteção radicam no conservadorismo que intenta manter a ordem e garantir a perpetuação do sistema hierárquico e excludente. De modo que o confinamento ao espaço privado dá conta da recusa ao aflorar da subjetividade pré-moderna, testemunhado pelo medo diante da liberdade que necessariamente recai sobre a negação e incompreensão do processo abolicionista.

Certa passagem de A menina morta ilumina o caráter simbólico do espaço. Trata-se da descrição do móvel que guarda a despensa da fazenda. Em face da relevância social do ambiente, a mera descrição toma outro vulto: o armário se faz metonímia da casa, assim como a casa se faz metonímia do país. A pujança dos objetos contrasta com o esvaziamento da experiência enclausurada em pequenas "casas" - móveis, gavetas, cofres. ${ }^{13}$

$\mathrm{O}$ corredor largo e escuro que conduzia à cozinha era como uma rua dentro da grande fazenda. Tudo passava por ali e a qualquer hora do dia podiam ser nele encontrados os habitantes do Grotão. Nos armários que ocupavam as paredes, nos lanços entre as poucas janelas gradeadas e abertas para o pátio interno eram guardados os artigos finos vindos do Rio de Janeiro e vindos de países exóticos e longínquos. Suas prateleiras conservavam por todo o ano o perfume forte e apimentado das gulodices, mandadas vir para as festas de Natal e fim de ano, e muitas vezes ali permaneciam durante meses, servidas em sobremesa para as visitas. Durante algumas gerações eles tinham sido os cofres de tesouros que só eram alcançados pelas crianças depois de muitas súplicas e de promessas de bom comportamento, e quase nunca era permitido às pequenas cabeças de cabelos encaracolados se alçarem até o nível das grandes caixas de madeira com gravuras de cores cintilantes, das latas cobertas de desenhos orientais ou figuras inglesas, ou ainda dos longos pacotes azuis rotulados de branco e cheios de letras estrangeiras. Deviam aguardar muito caladas, cá debaixo, a abertura das portas cujo rumor lhes parecia misterioso e solene, e que as pessoas abrissem lá em cima todas aquelas arcas e volumes de preciosidades, para receberem com reverência os quadrados de doces secos, os toletes de chocolate envolvidos em papel prateado, os cachos de passas com laços de fita vermelha, as ameixas muito negras e reluzentes, as nozes, avelãs e amêndoas que seriam ainda quebradas para ser comidas. Deviam receber esses dons com respeito e era necessário esperar que a senhora, em geral a governante, se preparasse para sair, para lá no jardim ou em plena mata, na sombra, poderem comer com sossego tudo aquilo, apesar das exclamações indignadas da professora. Perto da porta de entrada da sala de jantar que se levantava até o teto onde formava um arco de volta rebaixada, sustentado de cada lado por sóbrio ornamento, estavam colocados dois aparadores de madeira preta, onde posavam os pratos tirados da mesa para dali serem levados para a lavagem. Neles também eram colocadas as palmatórias que as pessoas quando iam 
deitar-se ou iam buscar qualquer coisa em seus quartos tiravam e acendiam a um candeeiro sempre aceso desde o escurecer. Na hora de todos dormirem o negro velho vinha enche-lo de novo de azeite, para assim ficar noite adentro até acabar. Com sua luz indecisa e fumarenta tinha de alumiar a longa extensão do corredor, que tomava proporções fantásticas e quem por ele entrava sentia a princípio a sensação de penetrar em gruta imensa, sem limites no alto e nos lados, pois suas paredes eram escuras, com os móveis sombrios, lisos e quase ameaçadores em sua severidade, mas logo a penumbra tudo absorvia, e todos instintivamente andavam nas pontas dos pés, com as mãos estendidas [...] (Penna, 2001, p.80-1, grifo meu)

A casa faz as vezes de uma cidade. Além de palácio, desvenda o caráter de microcosmo, magnificência do poder que emula um arremedo de vida pública. Seus corredores são ruas em que se encontram os moradores como se estivessem no espaço aberto. ${ }^{14}$ Porém, o espaço da vida compartilhada inexiste. O mundo reduz-se à casa e à família.

Após o narrador comparar os corredores às ruas e o trânsito doméstico à via pública, segue a descrição minuciosa dos víveres em armários suntuosos. A suposta neutralidade do recurso ao pormenor parece escolhida para substituir o exercício da vida em comum. Algo de naturalista sobrevive no caráter descritivista e na força do meio e das coisas como mediadores entre homens e mundo. No entanto, o romance não condiciona a função do ambiente à explicação dos destinos; ao contrário, o dado realista parece ser mobilizado a fim de gerar maior opacidade, em um mundo envolto em mistérios. ${ }^{15} \mathrm{~A}$ desusada descrição da variedade da despensa faz pensar em uma mercearia de luxo ao expor suas mercadorias. Mas não: nada ali está à disposição do homem livre, do trabalho ou da troca. Os armários são trancafiados e seus pertences furtados ou interditos surgem como bens inalcançáveis e signatários do poder. Tudo pertence a um dono invisível e as preciosidades são destinadas àqueles que melhor fizeram seu papel na manutenção do grande teatro.

A passagem remete à presença do espaço doméstico como impedimento em face do significado que emerge do espectro esvaziado do espaço externo, uma vez que esse só se organiza enquanto arena em que se situam iguais. O espaço externo é interno à casa, a amplidão inexistente do mundo se entronca, de súbito, ao relato dos objetos que se chocam com a sugestão da rua. Se a grande propriedade monocultora é o espaço da privatividade, da qual faz parte o grupo de parentesco e a escravaria, em um contexto em que a desigualdade é legitimada pela instituição da escravidão, o único espaço de vida permitido é o da família; daí a casa, corredores e aposentos simularem a convivência civilizada, desmentida constantemente pela base do trabalho compulsório. A propriedade e o grupo dominam todos os refolhos da práxis. Nada parece lhes faltar porque a queixa seria assombrosa afronta: os desejos pessoais, só possíveis no espaço da liberdade, não são sequer postulados. Os meandros do que é privado subsumem a autonomia afim à esfera da liberdade. 
A casa representa o próprio sistema da grande propriedade comandada pelo patriarca, sustentada pela escravidão, amparada pelo favor e à mercê da ameaça de dissolução em face do mundo livre. Assim ecoa a amplitude da metonímia, como diz a personagem Inacinha: "não tenho mesmo coragem de pensar em sair daqui, apesar de ter o pressentimento de aproximar-se o fim do Grotão" (Penna, 2001, p.472). O "fim do Grotão" implica o fim da estrutura de poder que, apesar da impiedosa opressão, é temido, uma vez que lhes garante algum lugar e autoconhecimento, salvaguardando-os contra o desconhecido. ${ }^{16}$

$\mathrm{Na}$ sequência da narrativa, a decadência do sistema se imprime na solidez da propriedade. Em meio à debandada dos moradores, em movimento análogo ao da natureza, a casa rui:

A estação das chuvas chegou, e naquela noite toda a fazenda ressoava ao som de mil tamborins, e parecia que pelos tetos imensos de enormes telhas romanas em declives rápidos, com os rebordos revirados, na lembrança dos tempos orientais, corriam tropas de guerreiros pigmeus, em manobras intermináveis, cheias de surpresas, de recuos e de assaltos velozes. Em contraste estranho com o silêncio dominante nas salas e nos corredores, onde apenas luzia a lamparina fumarenta, todo o rumor sonoro do telhado dos sótãos onde caíam de quando em quando enormes pedras, das tábuas a estalarem, dos ulos prolongados do vento em seus esforços para arrancar a pesada cobertura da casa, subdividida pelas claraboias e pelas construções a ela ligadas, formava longa música desesperada e alucinante. (Penna, 2001, p.435)

A derrocada do sistema é metaforizada pelo esboroamento da casa, do qual participam tanto as forças da história - uma vez que o processo é detonado por uma ação consciente - e da natureza - a dinâmica incontrolável das chuvas que se fazem tempestade e a tudo destroem. Por trás da magnificência do Grotão está a escravidão, cujas imagens adentram o espaço doméstico em cenas na cozinha, na visita das agregadas aos compartimentos da fazenda, na presença sinuosa das mucamas e dos negros da casa, cujo encargo, entre outros, era prover demandas e caprichos dos brancos, arcando com os inúmeros afazeres necessários para dar aos casarões rústicos o difícil conforto requerido pela fidalguia. ${ }^{17}$

Se entre a enunciação e o enunciado, em $A$ menina morta, há o fulcro da memória - uma vez que, publicado em 1954, o enredo recua e fixa-se no final do século XIX -, o palco da enunciação na Crônica da casa assassinada é a modernidade, fazendo coincidir ambos os momentos. Nesse sentido, trata-se da decadência que perdura, da queda como processo constante e inacabado em que o arcaico jaz conservado e reanimado por uma modernização peculiar. As estruturas ruinosas da casa são as da família ameaçada pela vinda de uma estrangeira: a singular Nina, cuja independência e liberdade abalará os alicerces do sistema.

Muitas são as imagens da casa na obra de Lúcio Cardoso; mas, a fim de entendê-las, há que considerar, em princípio, a peculiaridade da orquestração das vozes. Trata-se de um romance epistolar, o que implica presença de diversos 
narradores e, consequentemente, de múltiplos pontos de vista. Desse modo, as imagens da casa são leituras de mundo que ressoam nas subjetividades focalizadas.

O romance se abre com um mapa da casa dos Meneses. ${ }^{18}$ Em uma das imagens, note-se a flagrante associação entre casa e família: ambas perfazem um só corpo:

[...] Quem sabe, no fundo, também para ele [Timóteo] a Chácara signifique alguma coisa - talvez a herdade seja uma doença de sangue. Essas pedras argamassam toda estrutura interior da família, são eles Meneses de cimento e cal, como outros se vangloriam da nobreza que lhes corre nas veias. (Cardoso, 1997, p.122-3)

A passagem revela como a chácara funde-se se aos valores do clã, os quais reverberam o ideal de "nobreza". Como quem fala aqui é a amargurada Ana, esposa de Demétrio e rival de Nina, é sintomático que a propriedade, simulacro da aristocracia, seja designada como "doença de sangue”. Ana é, a um só tempo, representante da ordem e vítima da opressão, daí desvendar a matéria desalmada que perfaz a "estrutura interior da família”. Outras aparições da casa, sob narradores diversos, também desdobram o paradoxo de uma solidez ruinosa - da casa, da família, do patriarcado. A estrutura abalada, porém ainda firme, é a tradição que persevera, apesar das fissuras que o novo tempo da modernidade traz.

Certas formulações da mansão dos Meneses podem ser lidas como "imagens dialéticas" do processo histórico-social: ${ }^{19}$

Assim rumamos em direção à chácara, aquela velha chácara que sempre fora a lenda e o orgulho da pequena cidade em que vivíamos. Querelas, notícias de violências e de rivalidades me vinham ao pensamento - a lembrança do Barão, por exemplo, mais ilustre, mais rico e mais nobre que os Meneses, morando numa fazenda distante da cidade, mas cujo nome e cuja casa, apesar de tudo, não conseguiam ter em nosso pensamento o prestígio romântico da casa dos Meneses. E de onde vinha esse prestígio, que poder garantia a essa mansão em decadência o seu fascínio, ainda intacto como uma herança poética que não fora roída pelo tempo? Seu passado, exclusivamente seu passado, feito de senhores e sinhazinhas que haviam sido tios, primos e avós daquele Sr. Valdo que agora ia ao meu lado - Meneses todos, que através de lendas, fugas e romances, de uniões e histórias famosas, tinham criado a "alma" da residência, aquilo que, incólume e como suspenso no espaço, sobreviveria, ainda que seus representantes mergulhassem para sempre na obscuridade. Era o que eu sentia, enquanto o carro atravessava o portão central e ia deslizando pela areia empapada do jardim; ah, lamentava eu ainda, reconhecendo mesmo sob a chuva o perfume peculiar aos jardins da Chácara, esses Meneses não sabiam o que significavam para a imaginação alheia, o valor da legenda que lhes cercava o nome, sua força dramática e misteriosa, a poesia que os iluminava com uma luz frouxa e azulada. Sim, essas velhas casas mantinham vivo um espírito identificável, capaz de orgulho, de sofrimento e, por que não, de morte também, quando arrastadas à mediocridade e ao chão dos seres comuns. E não era isto o que acontecia, 
com a escória última daqueles Meneses que já não chegavam mais ao tope do prestígio mantido pelos seus antecessores? E de dentro da chuva cerrada quase sentia procurar-me da distância o olhar do velho prédio sacrificado, com estrias de sangue que escorressem ao logo de suas pedras mártires. (Terceira narrativa do médico). (Cardoso, 1997, p.285-6)

A significativa imagem é dada pelo relato do médico de província. O olhar exógeno permite que se aquilate a persistência do velho código senhorial. A cidadezinha encampa e propaga o prestígio decadente da família encarnado na casa. A fala deste narrador capta um processo de mitologização que não se limita ao poder econômico - uma vez que os Meneses estão empobrecidos e o Barão é "mais ilustre, mais rico e mais nobre" -; tinge-se de algo misterioso, insondável. O relato procura perscrutar a respeito de aspectos imponderáveis como a "alma" da residência e o caráter lendário que a cinge. $\mathrm{O}$ fragmento é significativo do poder que emana da casa, no sentido dos valores aristocráticos que se revestem de traço sobrenatural, evidenciando o discernimento turvado em face do mito da superioridade natural. Assim, a herança colonial acaba por conferir, a casa e aos seus, caráter aurático: o singular inviolável nas cercanias do mito. A contradição é reforçada pela persistência do passado senhorial em face da malignidade do novo. A perversa "herança poética”, o caráter lendário, a memória de "senhores e sinhazinhas" permanece, apesar da propriedade abrigar a "escória última daqueles Meneses". ${ }^{20} \mathrm{O}$ relato comprova o papel decrépito e alienante da família patriarcal cujos usos, valores e costumes se sobrepõem ao clamor contemporâneo de igualdade e individuação. Desse modo, a casa, literariamente configurada, revela-se constructo de ideologia e reflexão.

Em muitos momentos da narrativa, o espaço capta o páthos da experiência da subjetividade arruinada. $\mathrm{O}$ animismo que lhe empresta vida a faz detentora da vontade humana e má de matar. A casa assassinada também assassina; torna-se, a um só tempo, objeto e sujeito, é alvo e algoz, vítima e criminosa. Força lutuosa, contamina os moradores e assimila suas dores, numa espécie de via de mão dupla rumo à destruição: dissemina a impossibilidade de emancipação e traduz a voz da intolerância e da hierarquia, mas também estará sujeita à transitoriedade da matéria. Tradição e subjetividade parecem travar um pacto de morte.

A protagonista Nina, mulher cuja modernidade e encanto põem a perder o siso da família Meneses, constitui-se na antítese da ordem da casa. Ela encarna a interdita esfera do desejo e da liberdade humanas, acrescidas da beleza esfíngica e da volubilidade dos que não se deixam aprisionar. Sua fragilidade será paradoxalmente sua força: sob sua presença acelera-se a derrocada da casa-família-tradição. Desejada e proscrita, Nina encarna tudo o que a família anseia e teme.

O dinamismo do processo histórico, potencializado pela polifonia dos capítulos epístolas, inscreve-se no edifício e comunica-se com o corpo de Nina - o qual açambarca a juventude e a doença iminente. A chácara emulará um corpo em decomposição, colando-se à imagem da protagonista cujas carnes apodrecem em vida, intercambiando história e natureza. De modo que os opostos 
perfazem um só organismo que une vida e morte: o velho e o novo, a tradição e a ruptura - a casa e Nina.

A decadência, porém, não se inicia com a doença da invasora. O movimento ininterrupto de queda é onipresente e constante desde o início da narrativa. Muitas são as alusões a um presente que procura viver das sombras do passado. Memória da opulência, agora exânime, que se imprime no espaço e se incrusta nas subjetividades. O corpo social preservado à custa das vidas, emerge como corpo malsão, organismo eivado de morte, prestes a desfazer-se.

A prevalência do ambiente íntimo é também uma opção romanesca, uma vez que o lar e os limites concretos da vivência afinam-se à tendência introspectiva. Tal imperativo domina sobretudo em A menina morta e Crônica da casa assassinada. O recesso da casa, o quarto de dormir, as salas e as dependências dos escravos ou empregados são os espaços da ação dos romances. Os sujeitos como que vivem na redoma da grande propriedade que condiciona a aventura humana. Por vezes, a ação se produz antes na interioridade do que na exterioridade, atrelando-se à memória e à reflexão. A esse respeito, note-se que Fogo morto faz-se uma exceção, uma vez que, apesar da introversão, oferece mais diversidade espacial, abrangendo a casa-grande, o casebre e a vila.

Do despontar do trabalho livre (A menina morta) passando pela decadência do patriciado rural (Fogo morto) até as angustiantes reminiscências do fausto e do poder da família mineira (Crônica da casa assassinada), irrompe o esmagamento da subjetividade livre e emancipada, a consciência do fracasso e da culpa, a impossível autolibertação.

Com efeito, se o espaço da privatividade é o espaço da família, anterior à pólis, portanto avesso à conquista da cidadania, os sujeitos reduzem-se ao outro de si mesmos (Arendt, 2013). Ao dar-se conta de que a intimidade de suas correspondências fora violada, Carlota, por fim,

[...] descobria-se presa, limitada, prisioneira de alguma coisa difusa e rastejante, que a cercava de forma invisível e a tolhia sem algemas sensíveis, semelhante a ameaças de cegueira ou de surdez, companheiras dos velhos. (Penna, 2001, p.336)

A atrofia da práxis ecoa nos signos do inumano comandados por forças sociais que se fazem fabulosas: o invisivel e rastejante a prende, algema, cega e ensurdece.

Não é por acaso a recorrência ao tema que corta os três romances: o difícil processo de individuação em face da persistência do passado. O caráter de enclausuramento se refere à presença marcante da família, como se a arquitetura capturasse e zelasse pela memória dos seus. A grande propriedade é o reduto do clã cujo núcleo parental ampliado - parentes próximos, agregados e escravos - encontra-se submetido às ordens de um patriarca (Candido, 1951). O aprisionamento garante a perpetuação da estrutura de poder e legitima a família tributária da economia monocultora e da escravidão. A simbiose entre espaço e 
grupo estabelece contraponto com a exterioridade, expressa pela ordem da cidade, da individualidade. Ao incorporar todos esses significados, as casas tendem à antropomorfização: tornam-se casas-monstros, o sistema vivificado preserva $\mathrm{o}$ membro do grupo e condena a individualidade. Os fragmentos são expressivos:

A casa-grande subiu a cumeeira, as telhas brilhavam ao sol, a horta cresceu, o engenho subia as paredes, e com pouco o Santa Fé criava o seu corpo, era como gente viva, com os partidos de cana acamando na várzea. (Rego, 1971, p.136, grifos meus)

Entretanto, do outro lado da casa que parecia um grande e monstruoso animal adormecido junto das palmeiras imperiais, todas as vinte janelas rasgadas em sua fachada se alinhavam simetricamente, com as guilhotinas descidas e as portas de pau cerradas. (Penna, 2001, p.65, grifos meus)

E assim tudo continuava em sua aparência habitual, mas havia um princípio de desagregação, de ruína e desmoronamento que todos suspeitavam, e olhavam para o dono da casa como o único capaz de salvá-los, de tornar a fazer reviver e galvanizar aquele grande corpo que thes parecia agonizante, agitado pelo trabalbo subterrâneo da morte. (Penna, 2001, p.97, grifos meus)

Cada qual sentia no íntimo ter o Grotão se fendido de alto a baixo, na iminência de ruir, e algum mal estranho corroía suas entranbas... (Penna, 2001, p.267, grifos meus)

$\mathrm{Na}$ obscuridade, enquanto caminhava, vi a casa acesa, de janelas abertas, com uma ou outra sombra transitando em seus corredores; a Chácara, sempre mergulhada em sua calma, surgia diferente para quem conhecia seus hábitos. Era curioso de se ver, e havia certo encanto nisso - um sopro novo parecia alimentá-la e ela se erguia atenta, como na previsão de acontecimentos importantes. Não me lembrava de tê-la visto assim tão preparada, $e$ possivelmente me orgulharia de sua nova atitude, se não trouxesse o coração pesado e não pressentisse que, como certos doentes graves, ela só abrisse os olhos para celebrar o próprio fim. (Cardoso, 1997, p.470, grifos meus)

Quem quer que a visse de longe, estranharia seu aspecto de coisa invadida e violada. No entanto, na metamorfose que a alterava, e isto desde o cimo até sua mais secreta estrutura, havia um silêncio, uma espera que lhe emprestava um dignificante tom humano. Vendo-a, era impossível não reconhecer a importância do momento: como que em sua estática atenção, ela aguardava que a rajada passasse. Por cima, nos altos espaços que o céu azulava, percebia-se o estrondar da correnteza invisível, o vento, e era decerto a essa refrega que ela prestava atenção, com seus ouvidos de pedra, seus nervos de pedra, sua alma de pedra, silente e evocadora, como um instrumento de música morto na vastidão do campo. (Cardoso, 1997, p.474, grifos meus)

Instaura-se forte contraste entre a casa como organismo vivo, capaz de apreender os movimentos da natureza e da história, e a desvitalização dos sujeitos. A grande propriedade propaga a desindividuação, que confina o autoconhecimento à esfera da distinção de classe. Sob a esfera do patriarcado, todos reduzem-se a espectros, meros fantasmas: 
Era triste ter de retornar àquela habitação imensa, cheia de alcovas sombrias, cortada pelos corredores escuros e sonoros onde passavam fantasmas em pleno dia... (Penna, 2001, p.158, grifo meu)

Em certa medida, o estar em casa funciona como recusa ao enfrentamento da experiência, como se o confinamento pudesse prolongar a fixidez reconhecível, portanto falsamente confortável, do costume. O todo da composição romanesca mira a casa e atinge o que lhe é antitético, entrevendo a "rua": a centralidade da vida doméstica conterá o espectro esmaecido da vida pública, palco da modernidade, virtual espaço entre iguais (Arendt, 2013). Graças à compleição formal dos romances, o reduto familiar desvenda-se, perversa e significativamente, antes mundo que redoma.

\section{Da interdição à loucura: a casa como hospício}

Nesse percurso, o olhar para o caráter político do espaço romanesco observa mais uma dobra da figuração do confinamento: o engenho Santa Fé, a fazenda Grotão e a chácara dos Meneses evocam hospícios. A exigência aguda de controle, sob o imperativo da família, desemboca no seu oposto e a subjetividade fracassada encontra-se com a insanidade. Paira por sobre esse mundo comandado pelas casas-grandes a aniquilação da promessa da individualidade burguesa e os sujeitos, reduzidos ao núcleo familiar e indispostos à autonomia, acabam por apresentar fortes marcas de desequilíbrios psíquicos.

A ambiência do Santa Fé assemelha-se a um manicômio. Tanto o coronel Lula, quanto Olívia, moradores da casa-grande, dão conta da vertigem do mundo senhorial. Os pobres também colhem os respingos da irracionalidade do sistema: além da loucura de Marta, tanto Zé Amaro, quanto Vitorino trazem fortes marcas de desequilíbrios. O capitão amalucado, invectivando contra os poderosos e o seleiro atado à roda do ressentimento (Rufinoni, 2018).

A casa suntuosa e opressora do grande romance de Cornélio Penna é delineada como um palácio sombrio e mal-assombrado por cujos corredores perambulam seus moradores, inquietos e insatisfeitos, frequentemente em estados de semilucidez.

No Grotão, a inexistência de canais de desafogo para o sujeito é atroz: o trabalho compulsório, as primas empobrecidas, Carlota e Mariana como marionetes de um poder incontrolável. Todos sofrem as consequências da voragem do poder que enseja a atmosfera de desvario: “[...] e assim tentavam chamá-lo [ao padre] àquilo que para elas era a realidade, isto é, o meio delírio em que todas viviam" (Penna, 2001, p.210, grifo meu)

No romance de Lúcio Cardoso os desajustes se devem ao insustentável projeto de castração a que todos foram submetidos em nome da manutenção do antigo poderio. Dentre as interdições propagadas, emerge a aniquilação do desejo e do corpo, cuja resposta serão as transgressões ou pecados, dada a forte presença da religião. Ápice das castrações e impedimentos, a figura de Timóteo é exemplar. O filho pária dos Meneses, expulso do convívio da família e das 
vistas do mundo externo é, contudo, mantido nos limites da casa, em aposento secreto. Proscrito pelos seus em razão da homossexualidade, aceita o expurgo e sobrevive em meio ao desatino. Nina, a individualidade também banida, irá afrontar a proibição do contato. Aproximam-se em face da inobservância do lugar desejado, daí o despontar de certa camaradagem, o ensaio de certa solidariedade. No entanto, Timóteo não é apenas perseguido pela sua inadequação social; parte de seu delírio radica em uma curiosa, e talvez invertida, miragem de superioridade. Quando tomado pelo delírio, veste-se com as roupas de uma antepassada, mulher independente e ousada que também sofreu com os desmandos do grupo. De modo que a fantasia de vingança com laivos de emancipação comparte do código interno. Mesmo ao afrontar seus algozes, projeta a impossível independência por meio de uma figura do panteão familiar: renegada, porém endógena.

Ele, ao mesmo tempo, pertence e não pertence à ordem da casa: não pode dela se safar, mas resta aprisionado em um aposento oculto. A casa dentro da casa lembra a lógica dos hospitais gerais, locais que, destinados a apartar os doentes dos sãos, operavam como instituições jurídicas. ${ }^{21} \mathrm{~A}$ esse título, também a edícula, palco dos encontros clandestinos, torna-se espaço interno de fuga. Pois até a transgressão circunscreve-se nos limites do clã. Como se a casa pudesse - e devesse - dado seu caráter moral, guardar os pecados de família, controlando os corpos - lentamente assassinando-os, por assim dizer.

Os romances, cada um à sua maneira, captam a opressão da casa-família-país e suas consequências. Trata-se, portanto, da formalização introspectiva do descompasso de uma modernidade que se faz pelo atraso, do desenho de uma anomalia social que se engasta nas subjetividades. A prosa que diz o mundo através das personagens plasma, pelo crivo da introversão, a matéria social brasileira, como se o caráter "fora do lugar" da experiência histórica entalhasse a interioridade a golpes rudes, resultando em distúrbios psíquicos. ${ }^{22}$ Espectros da grande propriedade e da escravidão, a negação do indivíduo e da alteridade emerge como matéria social que molda a formação do sujeito moderno nacional. Consequências da introjeção de um sistema caduco, porém vigilante: sobrevivência residual, a fomentar a insanidade.

\section{Da loucura à morte: casas-túmulo}

É de notar que os três romances trazem a morte nos títulos. Dos matizes estruturais às significações afins, urge interpretar o destaque dado à morte: o engenho e a criança estão mortos e a casa, por sua vez, foi assassinada. Qual seria o sentido mais fundo dessa morte à qual os romances se referem?

De algum modo, em todos comparece a notação fúnebre, por vezes insólita, que articula a crise da grande propriedade à percepção da casa como grande túmulo cujos significados incidem sobre o peculiar processo de formação dos sujeitos.

Habitar e morrer são experiências contíguas. Alfredo Bosi já lembrou o quanto o ato de morar se articula à morte: a raiz comum vem de colo - a um só 
tempo morar e cultivar a terra - cujo particípio passado cultus abrange tanto a terra já lavrada, marcada pelo tempo da experiência, quanto o culto dos mortos. A terra cultuada "é sinal de que a sociedade que produziu seu alimento já tem memória" (Bosi, 1993, p.13), processo de enraizamento que também permite ao homem sepultar seus mortos, de modo que o abrigo da vida se comunica com o da morte. O caráter de acolhimento que a instante final encerra também é mencionado por Bachelard ao estabelecer parentesco entre o teto, o ventre e o túmulo. ${ }^{23}$

Contudo, a trama romanesca que retece sentidos absorverá a negatividade do processo civilizatório - cuja palavra base "cultura" também remonta a colo, do futuro culturus - e o abrigo, desprovido de conteúdo redentor, conterá sua antítese: será lápide e será cárcere. ${ }^{24}$

Acompanhem-se os eventos fúnebres dos enredos: Zé Amaro suicida-se, a menina está morta, Nina morre de câncer. Contudo, os sentidos vão além do conteúdo manifesto.

Em primeiro lugar, a articulação entre a casa e o significado histórico da decadência perpassa os três romances: seja a derrocada da economia do engenho diante das usinas (Fogo morto), as vésperas da abolição ameaçando a empresa cafeeira ( $A$ menina morta) ou o derradeiro golpe representado pela incontrolável presença do sujeito livre (Crônica da casa assassinada).

Em um segundo nível, o significado latente conduz à morte paulatina e constante do sistema. Concerne, ainda, ao tema da decadência, mas com a especificidade local de não se confundir com alguma destruição pontual e fulminante ${ }^{25}$ ao contrário, trata-se de uma morte que se insinua na vida, dos sentidos da queda que contaminam o fastígio e repercutem na modernidade - lembre-se que o luto de $A$ menina morta se nutre da opulência do ciclo do café; em Fogo morto, a rememoração do engenho grandioso contém os signos da ruína e, em Crônica da casa assassinada, o contemporâneo torna-se penosa expectação do ininterrupto fim.

Essa espécie de morte histórica a se infiltrar nas dobras de um regime cujas características se mantêm mesmo após a abolição faz pensar que a decadência é uma morte falhada, infinidade maligna, sempre reposta. Uma vez que os romances captam em diversos níveis o processo de desagregação do patriarcado, ao perseguir os conteúdos mais recônditos que a comparação entre os três romances possa aventar, os sentidos da morte comunicam-se com o alvorecer da individualidade sob o mundo livre.

No fecho de Fogo morto, o engenho Santa Fé morre: "não bota mais, está de fogo morto" (Rego, 1971, p.290). A extinção do engenho dará lugar ao tempo da modernização que trará o coronelismo - adotado por Zé Paulino e negado por Lula de Holanda - e as usinas. Mas o conluio do velho com o novo continua a expurgar os fumos de igualdade expressos quer pela fala de Zé Amaro, quer pela ação de Vitorino. Não mais escravos, não ainda livres: aporia a corromper a promessa de reconhecimento pessoal. 
Quanto ao romance de Cornélio Penna, ao luto em face da sinhazinha, que abre o romance e cujas emanações algo sacralizadas dominam a narrativa e se enovelam à atmosfera noturna e enigmática do romance, segue o proposital apagamento de sua imagem pelo poder. A dúplice condição da morte daquela que seria a continuidade do mando faz a aniquilação recair sobre o sistema, ecoando a abolição que será decretada pela sinhá moça, Carlota.

É sintomático que o desconhecimento em face da liberdade - lembrar que o enredo recua ao XIX brasileiro - a faça tributária da morte. Ao final, a dissolução da fazenda articula-se à ideia de uma certa liberdade. Num misto de pesar em face do desconhecido e de impulso à vida, a morte da casa dialoga, paradoxalmente, com o despontar da consciência. A enigmática exclamação de Carlota no fecho do romance pode ser lida nessa chave: a dos paradoxos intransponíveis da condição colonial. Como se o direito à escolha nascesse minado:

- Eu é que sou a verdadeira menina morta... eu é que sou essa que pesa agora dentro de mim com sua inocência perante Deus... Aquela que morreu e se afastou, arrancando do meu ser o seu sangue para desaparecer na noite, não sei mais quem é...e a mim me foi dada a liberdade, com a sua angústia, que será a minha força! (Penna, 2001, p.541, grifo meu)

Em Crônica da casa assassinada, certa cadeia de acontecimentos conduz ao assassinato da chácara dos Menezes - sentido que, por si só, remete à personificação -, propriedade que se cola à tradição e aos ecos escravistas e aristocráticos que sustém a família. Nina, o agente insidioso da destruição, será vítima da força da casa que, lenta e dolorosamente, esmagará a protagonista amalgamada às pedras do casarão. A ruína da protagonista e a da família são eventos intercambiáveis; após a morte de Nina, diz Timóteo à governanta Betty:

Era evidente que para ela (para Betty) só existia a morte de Nina, e nem poderia apreender jamais que outra qualquer espécie de morte estivesse tão iminente, e fosse uma morte fria, executada a capricho, com mãos trabalhadas para a perícia e o assassinato. (Cardoso, 1997, p.533)

A passagem é ambígua. Em nível manifesto, o agente da destruição é Timóteo, mas a julgar pelo encadeamento geral da narrativa, a ação pode ser praticada por Nina e pela própria casa - ambas emissoras da destruição. As "mãos trabalhadas para a perícia e o assassinato" empreendem "outra qualquer espécie de morte": o evento funesto se amplia abrangendo a devastação da família.

Em todos esses casos o que se vê é a aniquilação de uma possível subjetividade moderna e emancipada que jaz sob o peso da tradição aristocrático-escravocrata. Imperam os valores do grupo, apolíticos e excludentes, avessos aos direitos do indivíduo e às potencialidades próprias ao mundo do trabalho livre.

O avanço do colapso não garante um mundo aberto ao sujeito; a ideia mais funda da decadência não ambiciona um outro tempo, mas tece o novo com os fios do velho. Sob esse ponto de vista, os romances privilegiam sujeitos invisíveis socialmente: para os homens pobres e livres de Fogo morto e para todos 
em A menina morta, o espaço dos iguais ainda é impossível; já, em Crônica da casa assassinada, a desejável arena entre iguais é interditada, uma vez que o estatuto do sujeito moderno é de tal modo desqualificado que ainda emerge como afronta e desprestígio.

Se a experiência coletiva e ritualística da morte deveria guardar um possível sentido totalizador e altruísta, nos romances a tradição ancestral é substituída por uma série de significações contextuais que enfocam o modo como os traços do processo de modernização na periferia condicionam a fisionomia e o destino das personagens. Daí a escolha pelo viés introspectivo, cujos vários procedimentos formais procuram assimilar em nível profundo os percalços da formação do sujeito imerso na historicidade local.

A promessa de liberdade burguesa atrelada ao retrocesso imprime sua marca em todos: senhores, homens e mulheres pobres e livres e escravos. A liberdade será amarga uma vez que a sobrevivência residual da escravidão é imperiosa e não se apagam sem mais as marcas do cativeiro. Os três romances, apesar da diversidade, aproximam-se por meio seja do foco na privatividade, seja na formalização matizada da introversão, delineando angulações da mesma verdade histórica: a aventura da subjetividade em formação na transição entre escravidão e liberdade em face do patriarcado moribundo. O palco da vida privada será a casa, cujas acepções de prisão, hospício e túmulo acompanham as vicissitudes da experiência nacional.

Nesse caminho, uma das especificidades dos romances será que o paradoxo do foco nas subjetividades não resulta em autoconsciência ou profundidade filosófico-reflexiva por parte das personagens: tal ocorre por não lhes ser facultada nem a percepção de seu lugar social, nem a clareza acerca dos condicionamentos sociais do conflito vivenciado; daí o mal-estar da existência enveredar pela religiosidade mórbida, pela fuga via mito ou pelo giro em falso do ressentimento. Encastelados no universo apolítico da família, distantes da observância do estatuto da vida compartilhada, a marca dos sujeitos será a invisibilidade dos socialmente emudecidos ${ }^{26}$ fronteira do não ser no limiar da insanidade. Mas que não se confunda a precária autorreflexão conferida aos personagens com a construção da introspecção em termos do todo das composições. As diferentes formalizações da interioridade serão responsáveis pela captação em profundidade da formação e do esvaziamento dos sujeitos; ou seja, para além da incompletude das vozes da matéria narrada, o alcance do ponto de vista advém do êxito da arquitetura romanesca. Daí as peculiaridades: as vozes, a um só tempo, efusivas e inaudíveis dos pobres livres em contraste com o emudecimento do senhor arruinado, em Fogo morto; a feição fantasmagórica da introversão esvaziada em A menina morta; a intangível escrita da vida íntima, endereçada ao outro virtual, cuja visibilidade dependerá da complexa engenharia literária, no romance de Lúcio Cardoso.

A obstrução à ordem pública condiz com o patriarcado e seus resquícios, negá-la pressupõe a interdição à subjetividade e ao desejo, à cidadania e à voz. Postura que pressupõe a sobrevivência da ordem escravista, fundada na aniquila- 
ção do outro, ancorada na crença da desigualdade natural. $\mathrm{O}$ anacronismo da resistência à modernidade conduzirá os sujeitos à loucura e a outros desequilíbrios psíquicos. Daí também a recorrência aos modos da morte que não se reduzem aos títulos das obras, impelindo ao núcleo mais profundo, latente: o desvario e a morte-em-vida do sujeito entre a velha ordem e o mundo burguês, consequências de uma modernidade que se produz mediante a negação da liberdade e do outro.

Assim, para além de a terra onde se vive ser o chão onde se morre, a existência passa a ser um arremedo de vida, uma morte-em vida. Pode-se detectar a permanência do fracasso de que falou Mário de Andrade em nível mais diluído, porém não menos intenso, e por vezes inclusive embebido em atmosfera religiosa. ${ }^{27} \mathrm{~A}$ impraticabilidade do universo do ideal alimenta-se do sentido histórico de pós-utopia de que fala Luís Bueno como marco dos anos 1930: a negatividade que mina qualquer rota de fuga parece ser a regra para esses romances das décadas posteriores à experiência por ele analisada (Bueno, 2006). A ancoragem remete às vicissitudes da experiência da liberdade no país, limada de qualquer perspectiva revolucionária ou nostálgica - esta que, presente no ciclo da cana-de-açúcar, distante está de Fogo morto. É possível pensar no acréscimo de um caráter paralisante e melancólico ${ }^{28}$ a engessar ação e reflexão, índice do acirramento da perda de horizonte e descrença diante do projeto de país. Afastados da utopia do progresso dos anos de 1920, eivados do caráter crítico e representativo do país dos anos 1930, caberia indagar, ainda, acerca do momento da enunciação que enforma o ponto de vista dos romances produzidos nos decênios de 1940-1950. São romances modernos cuja leitura de país debruça-se sobre o passado, substituindo as questões contemporâneas pela reflexão sobre as velhas estruturas. Como se a chave para leitura do país estivesse alhures; como se os fumos desenvolvimentistas escondessem certa verdade incontornável. Nessa toada, o anacronismo aparente de romances que posicionam o país dentro de uma casa privilegia o conflito insolucionado - entre o arcaico e o moderno, o cativeiro e a liberdade, a família e o sujeito - e a história local que se descortina acumula escombros, negando um promissor porvir.

Se o país se assemelha a uma casa, também será cárcere, manicômio e cemitério. É sintomático que, ao absorver esteticamente os conflitos da modernidade nacional, o espaço familiar adquira fisionomias avessas à ordem. Note-se que as acepções aqui consideradas - prisão, hospício e túmulo - ultrapassam a feição da sociedade hegemônica, absorvendo justamente o que lhe é adverso, uma vez que constituem espaços de interdição e desterro. Um país dentro da casa: o palco conservador da recusa à liberdade e à igualdade avizinha-se das instituições de expurgo e acaba por assimilar o sujeito ao criminoso, a louco, ao morto. O confortável lócus do poder transmuta-se em espaço de exceção talvez porque, em nível profundo, e à luz dos direitos do indivíduo, assim o fosse. Logradouros de exílio, receptáculos dos resíduos da ordem: espaços de desvio, na contramão dos locais socialmente aceitos. ${ }^{29}$ Roupagens da casa que desnudam o país. 
1 Lembre-se o famoso prefácio a Cacau, comentado por Antonio Candido, no qual Jorge Amado opõe sinceridade à literatura. Diz Jorge Amado no referido prefácio: “Tentei contar neste livro, com um mínimo de literatura para um máximo de honestidade, a vida dos trabalhadores de cacau do sul da Bahia” (apud Candido, 2000, p.196).

2 Para o formalismo russo, por exemplo, o plano em que se enquadra o espaço é o da fábula, ou trama. Exceção feita a Bakhtin, cujo conceito de cronotopo articula espaço e tempo.

3 Aqui me valho, um tanto livremente, da menção de Foucault ao "espaço do dentro" $\mathrm{e}$ "espaço do fora” (Foucault, 2013, p.115).

4 O estudo de Gaston Bachelard (1990, p.87) A terra e os devaneios do repouso. Ensaio sobre as imagens da intimidade esquadrinha as imagens do elemento terrestre, entre as quais se encontra a casa. Entre as leituras da obra, tem-se que a casa, o ventre e a caverna são signos da profundidade imemorial que conduzem ao retorno à mãe. A casa é também analisada enquanto "arquétipo sintético" cuja "topografia onírica" associa a vida íntima aos espaços - daí porão e sótão conduzirem, respectivamente, ao inconsciente e ao consciente -, culminando com a ideia de repouso e abrigo. Para o autor, a casa constrói um contrauniverso, uma vez que habitar é estar protegido.

5 "O espaço em que vivemos, pelo qual somos lançados para fora de nós mesmos, no qual se desenrola precisamente a erosão de nossa vida, de nosso tempo e de nossa história, esse espaço que nos corrói e nos erode é também, em si mesmo, um espaço heterogêneo. Em outras palavras, nós não vivemos em uma espécie de vazio, no interior do qual seria possível situar indivíduos e coisas. Nós não vivemos no interior de um vazio que se revestiria de diferentes espelhamentos; nós vivemos no interior de um conjunto de relações que definem alocações irredutíveis umas às outras, e absolutamente não passíveis de sobreposição". (Foucault, 2013, p.115).

6 Bill Bryson (2011, p.19) introduz seu passeio pelas peculiaridades que, ao longo da história, o ato de morar suscita, por meio da investigação de uma casa comum de pároco de aldeia, dizendo: "Uma casa é um repositório incrivelmente complexo. O que descobri, para minha grande surpresa, é que tudo o que acontece no mundo - tudo o que é descoberto, ou criado, ou ferrenhamente disputado - vai acabar, de uma forma ou de outra, na casa das pessoas. As guerras, as fomes, a Revolução Industrial, o Iluminismo - tudo isso está lá, no seu sofá e na sua cômoda, escondido nas dobras de suas cortinas, na maciez dos travesseiros, na tinta das suas paredes, na água das suas tubulações. Assim, a história da vida doméstica não é apenas uma história de camas, sofás e fogões, como eu vagamente supunha, mas sim do escorbuto e do guano, da Torre Eiffel e dos percevejos, dos ladrões de cadáveres e de mais ou menos tudo o que já aconteceu. As casas não são refúgios contra a história. É nelas que os fatos históricos vão desembocar".

7 Segundo Pierre Bourdieu (2013, p.134-6): “A estrutura do espaço social se manifesta, assim, nos mais diversos contextos, sob a forma de oposições espaciais, o espaço habitado (ou apropriado) funcionando como uma espécie de metáfora espontânea do espaço social. Em uma sociedade hierarquizada, não existe espaço que não seja hierarquizado e que não exprima as hierarquias e as diferenças sociais de um modo deformado (mais ou menos) e, sobretudo, mascarado pelo efeito de naturalização acarretado pela inscrição durável das realidades sociais no mundo físico: diferenças 
produzidas pela lógica social podem, assim, parecer emergidas da natureza das coisas (basta pensar na ideia de 'fronteira natural')" [...] "O espaço social se encontra assim inscrito simultaneamente na objetividade das estruturas espaciais e nas estruturas subjetivas que são, em parte, o produto da incorporação dessas estruturas objetivadas" [...] "O espaço social não é o espaço físico, mas ele tende a se realizar de forma mais ou menos completa e exata nesse espaço. O que explica que tenhamos tanta dificuldade em pensá-lo enquanto tal, em estado separado. O espaço, tal como nós o habitamos e como o conhecemos, é socialmente marcado e construído. O espaço físico só pode ser pensado como tal por meio de uma abstração (geografia física); ou seja, ignorando-se decididamente tudo o que ele deve ao fato de ser um espaço habitado e apropriado, isto é, uma construção social e uma projeção do espaço social, uma estrutura social em estado objetivado $[\ldots]$ ".

8 Nas palavras de Henri Lefebvre (2013, p.125-6): “[...] o espaço aparece, se forma, intervém tanto em um dos 'níveis' [estrutura e superestrutura] como no outro. Tanto no trabalho e nas relações de dominação (de propriedade) como no funcionamento das superestruturas (instituições). Portanto, desigualmente, mas onde quer que seja. A produção do espaço não seria 'dominante' no modo de produção, mas articularia os aspectos da prática coordenando-os - reunindo-os em uma 'prática', precisamente”..

9 Caberia considerar as relações estreitas entre o evento menor, a casa como espaço da vida privada, o inconsciente e a prosa de introspecção. Sobre a primazia do acontecimento banal em certa linhagem do romance moderno, comenta Erich Auerbach (1986, p.493): “[...] confere-se menos importância aos grandes pontos cruciais externos e aos grandes golpes do destino, julga-se que são menos capazes de fornecer algo decisivo acerca do tema; existe, por outro lado, a confiança de que em qualquer fragmento escolhido ao acaso, em qualquer instante, no curso da vida está contida e pode ser representada a substância toda do destino”. Para Bachelard (1990, p.89), ao se constituir um contrauniverso, a casa remete à vida noturna, estabelecendo relações com o inconsciente: "Impossível escrever a história do inconsciente humano sem escrever uma história da casa”. Nota, ainda, certa homologia entre as imagens de intimidade, profundidade, enraizamento e repouso e a descida a si mesmo, no sentido da introspecção.

10 Segundo Luis Alberto Brandão (2013, p.58 e 65), o histórico das teorias do espaço no século XX leva a quatro abordagens: "representação do espaço; espaço como forma de estruturação textual; espaço como focalização; espaço da linguagem". A fim de ampliar tais limites, o autor propõe outros, os quais nomeia de "expansões do espaço literário" (representações heterotópicas, operações de espaçamento, distribuições espaciais, espaços de indeterminação). Do ponto de vista das Ciências Sociais, o debate contempla nomes como Barthes, Foucault, Lefebvre e Bourdieu (ibidem, p.73-85, e Lefebvre, 2013). Para os propósitos do estudo da casa em articulação com a história e subjetividades em formação, será preciso mobilizar a ideia de espaço como imagem, a qual permite acolher a multiplicidade e potencialidade da literatura. Do idealismo da imagem bachelardiana à imagem dialética benjaminiana em cujo bojo ganha força a premissa do espaço como espaço social.

11 Muita vez, o recorte específico e multifacetado do desenho da casa exigirá a mobilização de outras categorias como a da imagem dialética benjaminiana, por exemplo. Nesse sentido, a depender da elaboração estética, tal imagem pode ser lida de modos diversos, para além da mais ostensiva face metonímica. 
12 Para Bachelard (1984), a gruta é "cavidade perfeita" e "todo abrigo quer ser uma gruta”. "A gruta” (ibidem, p.141-60, p.158 e 144). O filósofo discorre a respeito da gruta enquanto espaço privilegiado: abrigo natural, morada sem porta que, ao unir o dentro e o fora, ao mesmo tempo, protege e garante a liberdade. No entanto, o termo também remete à tradição do grotesco como categoria estética tal qual estudada por W. Kayser. O termo vem do italiano grota (gruta), inicialmente usado para designar certa ornamentação antiga cuja peculiaridade era a de anular as delimitações entre as ordens do mundo. Com o tempo passa a designar um princípio estilístico que, presente em diversas artes, aborda os procedimentos de estranhamento que conduzem à sensação de mundo às avessas, atmosfera afim aos sentidos capturados pelo romance (Kayser, 1986).

13 A esse título, cabe mencionar um dos fragmentos das Passagens, de Walter Benjamin (2007, p.255). O filósofo analisa os interiores da vida burguesa do século XIX como uma vida dentro de estojos: "[...] é preciso entender o habitar, em sua forma mais extrema, como um modo de existência do século XIX. A forma primeva de todo habitar é a existência não numa casa, mas num casulo. Este traz a impressão de seu morador. A moradia transforma-se, no caso mais extremo, em casulo. O século XIX, como nenhum outro, tinha uma fixação pela moradia. Entendia a moradia como um estojo do homem [...]". A ideia da experiência confinada em caixinhas e cofres ou da vida miniaturizada é afim ao universo de Cornélio Penna.

$14 \mathrm{O}$ fragmento remete a Sérgio Buarque de Holanda ao comentar o caráter autossuficiente das casas-grandes, como se o privado subsumisse o público, como se as casas fossem vilas: "O engenho constituía um organismo completo e que, tanto quanto possível, se bastava a si mesmo. Tinha capela onde se rezavam missas. Tinha escola de primeiras letras, onde o padre-mestre desasnava meninos. A alimentação diária dos moradores, e aquela com que se recebiam os hóspedes, frequentemente agasalhados, procedia das plantações, das criações, da caça, da pesca proporcionadas pelo próprio lugar. Também no lugar montavam-se as serrarias, de onde saíam acabados o mobiliário, os apetrechos do engenho, além da madeira para as casas [...]”. Em seguida, cita a anedota contada por frei Vicente do Salvador, sobre o bispo de Tucumã para quem: "nesta terra andam as coisas trocadas, porque toda ela não é república, sendo-o cada casa” (Holanda, 2013, p.80-1).

15 Em estudo sobre L'Assomoir, de Zola, Antonio Candido (2004, p.63-7) analisa a função do meio e das coisas como "mecanismo condicionante" da narrativa e seus significados. De passagem, menciona a pouca atuação da causalidade na prosa moderna (Kafka e Beckett), pois o homem está lançado em um mundo que lhe é alheio.

16 Assim também nessa passagem o Grotão confunde-se com o sistema: "Devia ter soado em algum relógio a última hora do Grotão, que assim começava a se desagregar sem esperanças de novas forças e sem ninguém para poder avaliar qual seria também o seu destino..." (Penna, 2001, p.430).

17 Lúcio Costa (1962, p.175) esboça expressiva imagem da relação entre a grande propriedade e a escravidão: "A máquina brasileira de morar, ao tempo da Colônia e do Império, dependia dessa mistura de coisa, de bicho e de gente, que era o escravo. Se os casarões remanescentes do tempo antigo parecem inabitáveis devido ao desconforto, é porque o negro está ausente. Era ele que fazia a casa funcionar: havia negro para tudo, - desde negrinhos sempre à mão para recados, até negra velha, babá. O negro era esgoto; era água corrente no quarto, quente e fria; era interruptor de luz e botão 
de campainha; o negro tapava goteira e subia vidraça pesada; era lavador automático, abanava que nem ventilador".

18 O mapa da chácara, elaborado pelo próprio autor, testemunha a importância da delimitação espacial para o romance. $\mathrm{O}$ desenho atesta o destaque dado à propriedade que, nesse caso, como também ocorre em São Bernardo, figura no título. Cabe lembrar que algumas edições de Casa-grande e senzala, de Gilberto Freyre, também adotam procedimento semelhante: a obra se abre com um mapa da casa-grande, de autoria de Cícero Dias.

19 A esse título, leia-se a definição de imagem dialética de Walter Benjamin (2007, p.504): "Não é que o passado lança sua luz sobre o presente ou que o presente lança sua luz sobre o passado; mas a imagem é aquilo em que o ocorrido encontra o agora num lampejo, formando uma constelação. Em outras palavras: a imagem é a dialética na imobilidade. Pois, enquanto a relação do presente com o passado é puramente temporal e contínua, a relação do ocorrido com o agora é dialética - não é uma progressão, e sim uma imagem, que salta. - Somente as imagens dialéticas são imagens autênticas (isto é: não-arcaicas), e o lugar onde as encontramos é a linguagem” (cf. Brandão, 2013 , p. 99). A análise da imagem elencada parece corroborar tal conceituação.

$20 \mathrm{O}$ que pode remeter à reflexão de Foucault $(2013$, p.114) a respeito do caráter ainda sacralizado do espaço contemporâneo, que se pode aferir por meio de algumas oposições ainda intocáveis como "entre o espaço privado e o espaço público, entre o espaço da família e o espaço social [...]”. No contexto local, acrescente-se ao intocado o peso da herança colonial.

21 A respeito dessas casas de internamento, que surgem no século XVII, discorre Foucault (2012, p.50 e 53): “o Hospital Geral não é um estabelecimento médico. É antes uma estrutura semijurídica, uma espécie de entidade administrativa que, ao lado dos poderes constituídos, e além dos tribunais, decide, julga e executa”. Assim, sob a veste de instituição médica, “o gesto que aprisiona não é mais simples: também ele tem significações políticas, sociais, religiosas, econômicas, morais".

22 Pierre Bourdieu (2013, p.135): “O espaço social se encontra assim inscrito simultaneamente na objetividade das estruturas espaciais e nas estruturas subjetivas que são, em parte, o produto da incorporação dessas estruturas objetivadas". A alusão ao caráter "fora do lugar" da experiência histórica remete a Schwarz (1992).

23 O ventre como sarcófago ocorre nas imagens de Jonas (e a baleia) e do cavalo de Tróia, a partir das quais o filósofo tece considerações sobre a permutabilidade entre vida e morte: “[...] equivalência da vida e da morte: o sarcófago é um ventre e o ventre é um sarcófago. Sair do ventre é nascer, sair do sarcófago é renascer”. A passagem é coroada pela sentença: “A múmia é realmente a crisálida do homem” (Bachelard, 1984, p.137-8). Como se pode observar, os romances analisados vão na contramão desse postulado: a morte é desalento, ruína e danação. A presença da história na gênese dos objetos estéticos subverte o idealismo acrítico da divisa de Bachelard.

24 Conta Hélio Pellegrino (1997, p.785) que Lúcio Cardoso lhe presenteara com uma foto que trazia a seguinte dedicatória: "Esta é a casa em que comecei a morrer".

25 Em "Autenticidade do romance brasileiro", Carpeaux (1999) analisa a centralidade do tema da decadência nos romances brasileiros modernos, no sentido da recorrência à apreensão de um mundo em dissolução, ao contrário da emergência da modernidade.

26 "Invisibilidade" no sentido utilizado por Jacques Rancière (2009). 
27 No caso de A menina morta e Crônica da casa assassinada, cujos autores e enredos mobilizam questões da crise do homem no mundo, o fracasso comparece também sob o ponto de vista também religioso. Em depoimento, Lucio Cardoso critica a leitura do "fracassado", de Mário de Andrade. Para Lúcio, o herói do romance contemporâneo, da "literatura do desespero" posterior à Segunda Guerra, "não é bem um fracassado, mas um massacrado", "ser crispado" e "patético" que é "símbolo de nosso tempo". "Quase um manifesto" (in Cardoso, 1997, p.760-2). Cf. Andrade (1974).

28 Sobre a centralidade do caráter melancólico em A menina morta, ver Rufinoni (2010). Ver também Fernando Gil (1999) que, ao analisar Angústia, O amanuense Belmiro e Os ratos, estuda a recorrência do aspecto de paralisia e esvaziamento como sintomas do que chama de "romances da urbanização".

29 Michel Foucault (2012, p.116) nomeia tais espaços de heterotopias: locais não hegemônicos "absolutamente outros quanto a todas as alocações que eles refletem e sobre as quais falam". Uma das heterotopias descrita pelo filósofo compreende justamente os locais onde se encerram comportamentos considerados desviantes, como as prisões, os manicômios e os cemitérios. Coincidentemente, os mesmos locais aos quais conduz a interpretação da casa nos romances.

\section{Referências}

ANDRADE, M. de. A elegia de abril. In: Aspectos da literatura brasileira. 5.ed. São Paulo: Martins, 1974.

ARENDT, H. A condição humana. 1l.ed. Rio de Janeiro: Forense Universitária, 2013. AUERBACH, E. Mimesis - A representação da realidade na literatura ocidental. 2.ed. São Paulo: Perspectiva, 1986.

BACHELARD, G. A poética do espaço. In: Gaston Bachelard. Col. Os pensadores. São Paulo: Abril Cultural, 1984.

A terra e os devaneios do repouso. Ensaio sobre as imagens da intimidade. São Paulo: Martins Fontes, 1990.

BENJAMIN, W. Passagens. Belo Horizonte: Editora UFMG; São Paulo: Imprensa Oficial do Estado de São Paulo, 2007.

BOSI, A. Colônia, culto e cultura. In: __. Dialética da colonização. 3.ed. São Paulo: Cia. das Letras, 1993.

BOURDIEU, P. Espaço físico, espaço social e espaço físico apropriado. Revista Estudos Avançados, São Paulo, v.27, n.79, 2013.

BRANDÃO, L. A. Teorias do espaço literário. São Paulo: Perspectiva; Belo Horizonte: Fapemig, 2013.

BRYSON, B. Em casa: uma breve história da vida doméstica. São Paulo: Cia. das Letras, 2011.

BUENO, L. Uma história do romance de 30. São Paulo: Edusp; Campinas: Editora da Unicamp, 2006.

CANDIDO, A. The Brazilian family. In: SMITH, T. L.; MARCHANT, A. (Ed.) Brazil: Portrait of half a continent. New York: Dryden Press, 1951. 
CANDIDO, A. A revolução de 30 e a cultura. In: A educação pela noite e outros ensaios. 3.ed. São Paulo: Ática, 2000.

Degradação do espaço. In: O discurso e a cidade. 3.ed. Rio de Janeiro: Ouro sobre Azul; São Paulo: Duas Cidades, 2004.

CARDOSO, L. Crônica da casa assassinada. Edição crítica, Mário Carelli (Coord.). Madri; Paris; México; Buenos Aires; São Paulo; Lima; Guatemala; San José de Costa Rica; Santiago do Chile: ALLCA XX; Scipione Cultural, 1997. (Coleção Archivos, n.18).

CARPEAUX, O. M. Autenticidade do romance brasileiro. In: Ensaios reunidos. 1942-1978. Rio de Janeiro: Topbooks, 1999. v.I.

COSTA, L. Depoimento de um arquiteto carioca. In: XAVIER, A. (Org) Lucio Costa: sobre arquitetura. Porto Alegre: Centro de Estudantes Universitários de Arquitetura, 1962.

DaMATTA, R. Casa, rua e outro mundo: o caso do Brasil. In: A casa \& a rua. Espaço, cidadania, mulher e morte no Brasil. 5.ed. Rio de Janeiro: Rocco, 1997.

FOUCAULT, M. A grande internação. In: História da loucura: na Idade clássica. 9.ed. São Paulo: Perspectiva, 2012.

De espaços outros. Revista Estudos Avançados, São Paulo, v.27, n.79, 2013.

FREYRE, G. Casa-grande é senzala. Introdução à história da sociedade patriarcal no Brasil - 1. 4l.ed. Rio de Janeiro: Record, 2000.

Sobrados e mucambos: decadência do patriarcado rural e desenvolvimento urbano. São Paulo: Global Editora, 2004.

GIL, F. O romance da urbanização. Porto Alegre: EDIPUCRS, 1999.

HOLANDA, S. B. de. Raizes do Brasil. 26.ed. São Paulo: Cia. das Letras, 2013.

KAYSER, W. Ogrotesco. São Paulo: Perspectiva, 1986.

LEFEBVRE, H. Prefácio - A produção do espaço. Revista Estudos Avançados, São Paulo, v.27, n.79, 2013.

PELLEGRINO, H. Um indomável coração de poeta. In: CARDOSO, L. Crônica da casa assassinada. Edição crítica, Mário Carelli (Coord.). Madri; Paris; México; Buenos Aires; São Paulo; Lima; Guatemala; San José de Costa Rica; Santiago do Chile: ALLCA XX; Scipione Cultural, 1997. (Coleção Archivos, n.18).

PENNA, C. A menina morta. Rio de Janeiro: Artium, 2001.

REGO, J. L. do. Fogo morto. Rio de Janeiro: Editora José Olympio; INL, 1971.

RANCIÈRE, J. A Partilha do sensível: estética e politica. São Paulo: Editora 34, 2009.

RUFINONI, S. R. Favor e melancolia: estudo sobre A menina morta, de Cornélio Penna. São Paulo: Edusp; Nankin, 2010.

À sombra da casa-grande: patriarcado, loucura e ressentimento em Fogo mor-

to. Teresa: revista de literatura brasileira, São Paulo, FFLCH/USP, n.19, 2018.

SCHWARZ, R. As ideias fora do lugar. In: Ao vencedor as batatas. São Paulo: Duas Cidades, 1992.

XAVIER, A. (Org.) Lucio Costa: sobre arquitetura. Porto Alegre: Centro de Estudantes Universitários de Arquitetura, 1962. 
RESUMO - A partir da análise do espaço da casa, o estudo comparativo dos romances Fogo morto, de José Lins do Rego (1943), A menina morta, de Cornélio Penna (1954), e Crônica da casa assassinada, de Lúcio Cardoso (1959), permite entrever complexo quadro de relações entre forma romanesca e sociedade brasileira. São romances cujos enredos transcorrem no interior ou à sombra do espaço doméstico cujo significado aponta para as especificidades da sociedade brasileira ancorada na estrutura e no funcionamento do modo de produção escravista, expresso pela significativa presença do lar como casa-grande. Ao formular as especificidades locais, a casa-país transfigura-se em prisão, hospício e espaço tumular.

PALAVRAS-CHAVE: Casa-grande, Patriarcado, Família, Prisão, Loucura.

ABSTRACT - From an analysis of the space of the home, a comparative study of the novels Fogo Morto, by José Lins do Rego (1943), A menina morta, by Cornélio Penna (1954), and Crônica da casa assassinada, by Lúcio Cardoso (1959), allows a glimpse into a complex framework of relations between novelistic form and Brazilian society. These are novels that take place in the interior or in the shadow of the domestic space, whose meaning points to the specificities of Brazilian society anchored in the structure and functioning of the slave-based mode of production, expressed by the significant presence of the home as casa-grande. By formulating local specificities, the house-country is transfigured into a prison, a lunatic asylum and tomb space.

KEYWORDS: “Casa-grande”, Patriarchy, Family, Prison, Madness.

Simone Rossinetti Rufinoni é professora de Literatura Brasileira do Departamento de Letras Clássicas e Vernáculas da Faculdade de Filosofia, Letras e Ciências Humanas da USP. @-siruf@hotmail.com / https://orcid.org/0000-0002-7915-8913

${ }^{\text {I }}$ Faculdade de Filosofia, Letras e Ciências Humanas, Universidade de São Paulo, São Paulo, Brasil.

Recebido em 10.5.2019 e aceito em 22.7.2019. 